\title{
MELACAK MAKNA KONSEP KERUPAAN PADA LAMBANG INSTANSI DI INDONESIA DENGAN SUMBER BENTUK MATAHARI (Studi Kasus Perkembangan Bentuk Surya Majapahit)
}

\author{
Wisnu Adisukma \\ Program Doktor Pascasarjana Institut Seni Indonesia (ISI) Surakarta \\ wisnuadi@isi-ska.ac.id
}

\begin{abstract}
The article tittled Melacak Makna Konsep Kerupaan Pada Lambang Instansi di Indonesia dengan Sumber Bentuk Matahari is intended to pursue the textual and contextual meaning of institution sign with basic shape of sun. With iconographic approach would be obtained deeper and broader meaning from a work of art. Through this approach, the artwork will be a major concern in reviewing the history of art, nevertheless still necessary to understand the contextual and symbolic aspects. As the results, sign with basic shape of sun is the cosmic center, cental, foundation point, origin, sangkan paran, or axis mundi. Therefore, it is as the sun that is the problem solving of many problematics in its era.
\end{abstract}

Keywords: Iconography, Meaning, Sign, Sun.

\begin{abstract}
ABSTRAK
Artikel dengan judul Melacak Makna Konsep Kerupaan Pada Lambang Instansi di Indonesia dengan Sumber Bentuk Matahari dimaksudkan untuk mencari makna tekstual dan kontekstual dari lambang instansi yang menggunakan bentuk dasar matahari. Dengan pendekatan ikonografi akan diperoleh pemaknaan yang lebih dalam dan luas dari sebuah karya seni. Melalui pendekatan ini, maka karya seni akan menjadi perhatian utama dalam mengkaji sejarah seni, meskipun demikian juga dibutuhkan pemahaman pada aspek konstektual dan simbolik. Hasil yang diperoleh, bahwasanya lambang-lambang dengan bentuk dasar matahari sama-sama beranggapan sebagai merupakan poros kosmis, pusat, titik asal muasal, akar segala akar, sangkan paran, atau axis mundi. Sehingga beranggapan sebagai pencerah sebagaimana matahari yang mampu menjadi problem solving bagi problematika yang dihadapi di zamannya.
\end{abstract}

Kata kunci : Ikonografi, Lambang, Makna, Matahari 


\section{PENDAHULUAN}

\section{A. Latar Belakang}

Perkembangan lambang ataupun logo merupakan suatu kebutuhan dari sebuah instansi atau perusahaan sebagai 'pembeda' antara yang satu dengan yang lain. Istilah lambang dan logo jika mengacu pada Kamus Besar Bahasa Indonesia memiliki kesamaan arti, yaitu sama-sama mengandung makna tertentu. Walaupun dalam dunia desain, khususnya Desain Komunikasi Visual, istilah lambang jauh lebih lama digunakan dibandingkan dengan istilah logo.

Penggunaan logo, menurut Online Etymology Dictionary (Douglas Harper, 2010), dijelaskan bahwa kata logo baru muncul tahun 1937. Logo merupakan kependekan dari istilah logotype, sehingga sebelum tahun tersebut, orang lebih menggunakan istilah lambang. Peruntukan istilah logo cenderung mengarah pada munculnya produk dengan perusahaan yang berbeda, sehingga agar berbeda dengan yang lain, menggambarkan visi misi perusahaan, jaminan kualitas terhadap produk dari perusahaan tertentu melatarbelakangi munculnya logo. Artikel ini tidak membahas pembedaan bahasa menurut etimologi antara lambang dan logo, sebab substansi dari lambang dan logo adalah mirip. Sehingga lambang dalam artikel ini diidentikkan dengan logo yang dipahami para desainer komunikasi visual.

Lambang merupakan bagian identitas yang mewakili sifat, ciri, ataupun visi dan misi dari seorang tokoh maupun organisasi tertentu. Lewat lambang atau logo maka masyarakat percaya pada keagungan atau karakter kuat yang divisualisasikan pada bentuk rupa suatu lambang, karena didalamnya terdapat beberapa simbol yang ditampilkan melalui macam-macam jenis gambar tertentu yang memiliki makna bahkan falsafah tersendiri. Lambang dengan bentuk dasar matahari merupakan lambang yang banyak digunakan di Indonesia meski muncul secara tersirat. Kebanyakan lambang dengan bentuk dasar matahari kini digunakan oleh institusi yang bernafaskan Islam, dan anehnya lambang toko Matahari (Matahari department store) yang jelas menyebut matahari justru tidak memunculkan gambaran bentuk matahari. Penggunaan bentuk dasar matahari sebagai lambang dipercaya mulai digunakan pada masa Majapahit, yang dikenal dengan Surya Majapahit. Pasca Majapahit, lambang-lambang berbentuk dasar matahari tetap digunakan, uniknya pada masa kini lambang dengan bentuk dasar 
matahari lebih banyak digunakan oleh instansi yang notabene-nya berlatar agama Islam baik organisasi kemasyarakaran, organisasi politik, hingga institusi pendidikan tinggi. Hal tersebut tentulah menjadi kemenarikan tersendiri jika ditinjau dari sejarah, justru lambang dengan bentuk dasar matahari jarang bahkan tidak digunakan oleh institusi Islam.

Menilik kembali sejarah, Majapahit dipercaya merupakan kerajaan Hindu-Budha terakhir sebelum kejayaan kerajaan Islam di Jawa. Berpusat di Jawa Timur, Majapahit merupakan rentetan panjang dinasti besar Hindu-Budha dalam sejarah Jawa setelah pusat kerajaan bergeser dari Jawa Tengah (Mataram Kuna). Kerajaan Majapahit dipercaya hancur karena serangan kerajaan Demak, dan sejak Majapahit ada di bawah pemerintahan kerajaan Demak, Islam berkembang pesat di Nusantara. Namun anehnya, lambang Surya Majapahit tetap dilestarikan oleh kerajaan Demak yang dianggap meruntuhkan kerajaan Majapahit. Hal tersebut dibuktikan dengan adanya lambang Surya Majapahit yang berada di dalam Masjid Agung Demak yang tertempel pada tembok di atas mihrab (ruang imam memimpin sholat). Tentulah hal ini menjadi keunikan jika menyoal kerajaan dengan dasar agama yang berbeda, namun tetap melanggengkan bentuk lambang kerajaan yang dihancurkannya. Penerusan lambang dengan bentuk dasar Surya Majapahit pastilah memiliki makna penting sehingga tetap diuri-uri.

Menurut P.J. Zoetmulder (1971: 88), penerusan budaya terhadap artefak seni klasik akan tetap ada sebab karya seni klasik memiliki wawasan yang sempurna serta makna yang dalam. Zoetmulder menekankan bahwa makna karya klasik hanya mampu terpahami melalui lubuk yang terdalam atas kebenaran dan kenyataan, yang tetap tersembunyi untuk orang awam. Karya seni klasik tersebut akan terungkap dengan sendirinya untuk mereka yang berpengetahuan, yang mampu menembus makna yang paling dalam.

Sampai saat ini, kepercayaan akan adanya kekuatan spiritual di karya seni klasik yang berakar dari budaya Jawa asli tetap dipertahankan melalui perkembangan bentuk dengan sinkretisme agama dan budaya, tetapi meski wujudnya berkembang damun makna budaya asli tidak berubah. Dalam arti tertentu, penelitian tentang lambang instansi yang bersumber dari bentuk matahari berusaha menyumbangkan pemahaman mengenai makna budaya asli yang terkandung pada lambang tersebut. Meskipun bentuk lambang berkembang sesuai dengan kebutuhan, namun substansi hingga esensi bentuk dasar matahari dalam budaya asli Nusantara dimungkinkan tidak berubah. Bentuk dasar dan makna lambang bentuk matahari inilah yang akan dikupas dalam 
artikel agar lebih terfokus dan tersusun secara sistematis berdasarkan latar belakang masalah di atas melalui kajian ikonografi.

\section{Metode Penelitian}

Jenis penelitian yang digunakan adalah penelitian kualitatif dengan metode penelitian pustaka yaitu analisis wacana dari berbagai sumber literasi baik data dari buku, data dari artikel ilmiah baik jurnal cetak maupun online, arsip, dan sumber data dokumen berwujud teks lainnya. Langkah awal yang digunakan oleh penelitian adalah memilih objek kajian yaitu lambang instansi dengan sumber bentuk matahari. Lambanglambang ini bermula dari lambang Surya Majapahit, dan dimungkinkan karena kebesaran nama Majapahit, akhirnya lambang berbentuk dasar matahari dipertahankan dan dikembangkan hingga kini. Penulis mengkaji beberapa lambang dengan betuk dasar matahari yaitu Surya Majapahit, Surya Sumirat Mangkunegaran, lambang Muhammadiyah dan beberapa lambang di bawah organisasi Muhammadiyah, lambang Persatuan Islam (Persis), hingga lambang institusi pendidikan seperti UIN dan lambang Parpol yaitu PAN. Teknik pengumpulan data diperoleh melalui studi pustaka, dan pengamatan.

Kerangka teoritis dalam artikel ini adalah kerangka sejarah seni. Hal ini dilandasi pemahaman bahwa seni adalah ekspresi dari budaya yang melatarbelakanginya. Dalam ungkapan sejarawan seni dari Jerman, Erwin Panofsky (1975: 41), karya seni didefinisikan sebagai gejala dari sesuatu yang lain. Dengan teori ikonografi dan metode ikonologis Erwin Panofsky diharapkan dapat memahami dan menganalisis maknamakna yang terkandung dalam lambang instansi dengan bentuk dasar matahari. Menurut Erwin Panofsky untuk memperoleh makna dari suatu karya seni harus mengikuti tiga tahapan yang sifatnya prerequisite atau berurutan dan saling terkait satu sama lain. Terdiri dari tahapan pre-ikonografi, analisis ikonografi, dan interpretasi ikonologi (Panofsky, 1955: 26).

\section{Tahap pertama, tahap pre-ikonografi}

Merupakan tahapan untuk mengidentifikasi dan mendeskripsikan fenomena karya seni berdasarkan pada ciri-ciri visual yang tampak seperti: konfigurasi garis, warna, bentuk, teknik, material yang digunakan, dan lain-lain. Pada tahapan ini karya seni dideskripsikan secara faktual dan ekspresional. Makna faktual dipahami dengan cara 
mengidentifikasi bentuk yang tampak pada objek karya seni. Makna ekspresional dipahami berdasarkan kejadian (events) yang terlihat di dalam karya berdasarkan pengalaman praktis (practical experience) dari pengamat. Deskripsi formalistik ini kemudian dikonfirmasikan menggunakan prinsip korektif pada sejarah gaya/style (Panofsky, 1955: 26).

Untuk mendukung analisis pada tahap pre-ikonografi ini diperlukan teori-teori seni sebagai teori pendukung, diantaranya teori yang berkenaan dengan struktur seni. Untuk mengkaji struktur seni pada karya Praktik Tentara Pendudukan Asing akan digunakan teori dari Edmund Burke Feldman dan Herbert Read. Menurut Feldman dalam bukunya Art as Image and Idea dijelaskan bahwa struktur karya seni terdiri dari: a) elemenelemen seni rupa (garis, bentuk, tone/ gelap-terang, dan warna), b) pengorganisasian elemen seni (kesatuan, keseimbangan, ritme, dan proporsi) dan c) kontribusi penikmat terhadap karya seni (Feldman, 1967: 222-278). Demikian juga yang dikatakan oleh Herbert Read dalam bukunya The Meaning of Art bahwa elemen karya seni rupa terdiri dari: garis, tone/ gelap-terang, warna, bentuk, dan kesatuan (Read, 1972: 49-65). Pelacakan pseudo-formalistik di tahap ini adalah sebagai syarat untuk memperoleh kepastian mengenai gaya bentuk lambang tersebut.

Pemahaman mengenai gaya merupakan syarat yang tidak bisa dihindari dalam mempelajari sejarah seni rupa. Gaya akan memperlihatkan kecenderungankecenderungan ekspresi visual yang bisa dikelompokkan atau diklasifikasikan untuk menentukan gaya berdasar waktu, wilayah, teknik, subject matter, dan lain sebagainya. Dengan memperoleh pemahaman mengenai gaya karya seni akan membantu untuk membaca "hidden language" dari karya seni.

\section{Tahap kedua, tahap analisis ikonografis}

Proses membaca arti sekunder dari aspek tekstual (ciri-ciri visual/motif artistik) dengan melihat hubungan antara ciri visual sebuah karya seni dengan tema dan konsep berdasarkan interpretasi dari imaji atau gambar, cerita, dan alegori (kiasan atau perlambangan). Untuk itu diperlukan kajian-kajian kepustakaan sebagai pendukung berupa berbagai teori seperti antropologi, sosiologi, sosial-budaya, atau gaya hidup, karya-karya sastra, filsafat, dan lain sebagainya sesuai konteks karya yang dikaji. Tema atau konsep yang spesifik diekspresikan oleh objek karya seni dan kejadian (events) di dalam karya tersebut. 


\section{Tahap ketiga, tahap interpretasi ikonologis}

Tahap ini merupakan tahapan untuk memberikan makna intrinsik atau simbolik yang subtil atau mendasar dari objek karya seni agar bisa memastikan prinsip-prinsip filosofis karya seni pada suatu zaman. Pada tahap ini diperlukan intuisi sintetik berdasar pada kondisi psikologis dan weltanschauung atau pandangan hidup dari pengamat. Prinsip korektif pada tahapan ini menggunakan gejala-gejala budaya sesuai konteks dari objek.

Pada tahapan ini, pemaknaan terhadap lambang instansi dengan bentuk dasar matahari akan dilakukan dengan menggunakan teori simbol dari Suzanne Kangsley Langer. Menurut Langer, simbol dibedakan menjadi dua jenis, yaitu: simbol seni dan simbol di dalam seni. Simbol seni disebut juga dengan bentuk ekspresi, sebagai ekspresi dari jalinan antara sensibilitas, emosi, perasaan, dan kognisi impersonal, yang merupakan ciri utama dari karya seni. Simbol seni dikatakan juga sebagai citra absolut (tidak terbatas), citra yang sebaliknya akan menjadi irasional karena secara harfiah tidak tergambarkan. Sementara yang dikatakan simbol di dalam seni adalah arti perlambangan yang dimuatkan pada karya tersebut atau sebuah metafora, sebuah citra dengan signifikansi harfiahnya yang jelas ataupun tersamar. Dengan demikian, menurut Langer, seni adalah sebuah simbol dan sekaligus juga bermuatan simbol (Suzzane K. Langer, Problematika Seni, 2006: 139-140).

\section{HASIL DAN PEMBAHASAN}

\section{A. Tahap Pertama: Tahap Pre-lkonografi}

Dalam tahapan pertama ini, hal terpenting yang harus dilakukan adalah mengidentifikasi dan mendeskripsikan karya seni rupa berdasarkan pada ciri-ciri fisik atau visual yang tampak seperti: konfigurasi garis, warna, bentuk, teknik, material yang digunakan, dan lain-lain. Pada tahapan ini karya seni dideskripsikan secara faktual dan ekspresional. Makna faktual dipahami dengan cara mengidentifikasi bentuk yang tampak pada objek karya seni. Makna ekspresional dipahami berdasarkan kejadian (events) yang terlihat di dalam karya berdasarkan pengalaman praktis (practical experience) dari pengamat. 
Dengan memperoleh pemahaman mengenai gaya karya seni akan membantu untuk membaca "hidden language" dari karya seni. Gaya karya seni sendiri dapat dideteksi melalui unsur-unsur seni rupa dan hubungan kualitatif antara elemenelemennya. Untuk memperoleh kepastian mengenai gaya karya seni, pada tahapan ini juga akan diperbandingkan dengan antara lambang yang pertama muncul yaitu Surya Majapahit dan lambang-lambang dengan bentuk matahari yang lain.

Diketahui bahwa, gambar surya yang dijadikan ornamen pada sebuah lambang mulanya berasal dari kerajaan Majapahit. Meski sebelum abad ke-10 sudah berdiri sejumlah kerajaan besar di Nusantara, lambang dari Kerajaan Majapahit (1293-1500) adalah identitas tertua dari kerajaan Nusantara yang masih dapat diidentifikasi. Sebuah ornamen yang dikenal dengan nama Surya Majapahit, sementara banyak dianggap sebagai lambang kerajaan yang pernah mencapai kejayaannya di seluruh penjuru Nusantara itu. Surya Mapapahit adalah ornamen yang umumnya ditemui di situs- situs peninggalan Majapahit. Ornamen ini dapat ditemukan di langit-langit garbhagriha, salah satu ruangan tersuci di Candi Penataran. Ornamen ini juga ditemukan di Candi Bangkal (Mojokerto), Candi Sawentar (Blitar) dan di batu-batu nisan yang berasal dari zaman Majapahit di seputar wilayah Trowulan (Mojokerto).
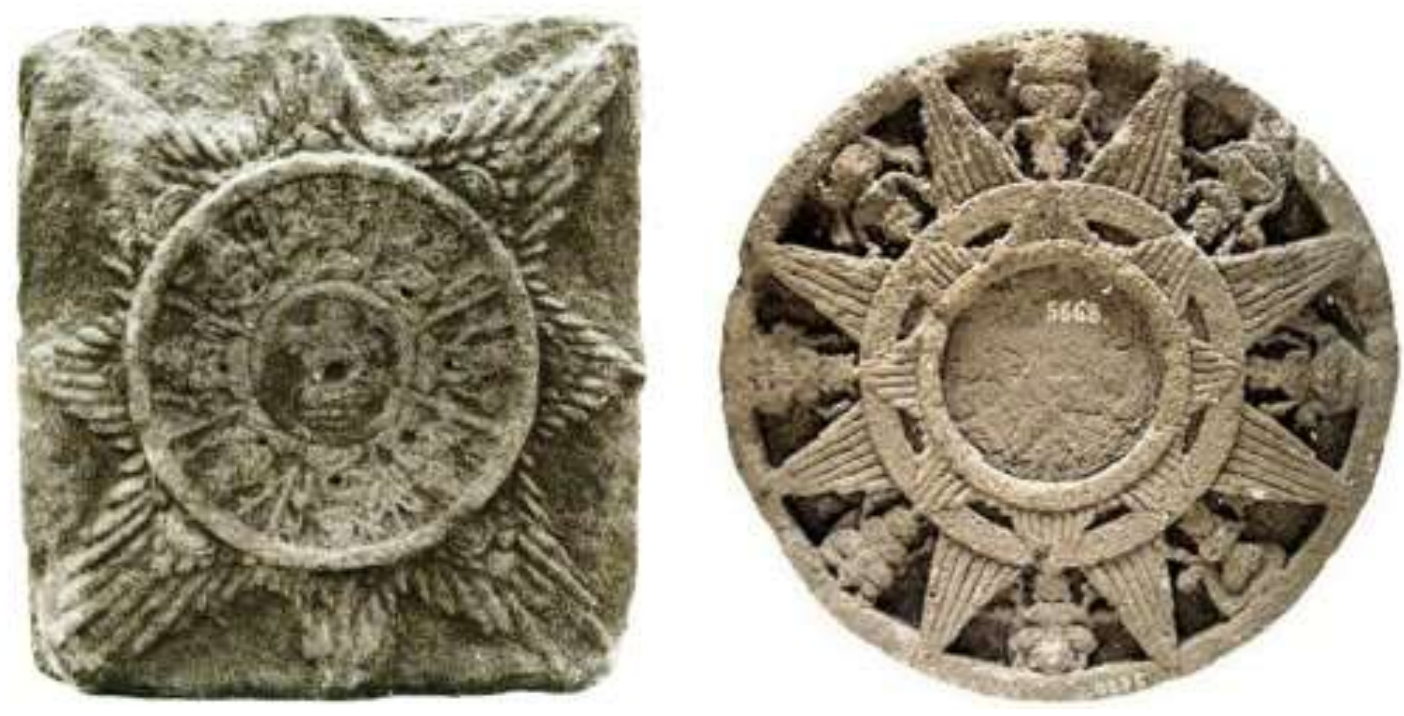

Gambar 01. Lambang Surya Majapahit masa Tri Bhuana Tunggadewi serta Hayam Wuruk (kiri) dan Lambang Surya Majahit era Ratu Suhita (kanan) 
Kerajaan Majapahit hingga kini masih menjadi salah satu pijakan kebudayaan di Indonesia, sebab kerajaan Majapahit dipercaya pernah mencapai puncak kejayaan dengan mempersatukan Nusantara. Kerajaan yang memiliki nama asli Wilwatikta dalam sejarahnya dinyatakan mencapai puncak kejayaan di bawah pemerintahan Hayam Wuruk dengan Gajah Mada sebagai Mahapatih. Nagarakretagama pun menceritakan pada pupuh 13 dan 14 bahwa pengaruh kerajaan Majapahit sampai Madagaskar dan Sri Langka. Hal tersebut dibuktikan dengan persembahan upeti, yang dianggap sebagai pengakuan kekuasaan Majapahit atas daerah yang bersangkutan (Prof. Dr. Slamet Muljana, 2006, hlm. 161-168).

Komposisi lambang Surya Majapahit menggunakan komposisi simetris dan proporsional. Bentuk Surya Majapahit mengalami perkembangan, sebagaimana yang ditampilkan terdapat lambang Surya Majapahit masa Prabu Hayam Wuruk dan masa ratu Suhita. Bentuk dasar pada lambang masa prabu Hayam Wuruk berbentuk persegi dan terdapat dua buah lingkaran, dengan lingkaran kecil di tengah sebagi pusat. Lingkaran besar bergambar dewa penjaga delapan penjuru mata angin (Dewata Nawasangha). Pancaran sinar yang diasosiasikan sebagai matahari memancar, diwujudkan dalam delapan arah pancaran yang merujuk pada delapan arah mata angin.

Sedangkan lambang Surya Majapahit masa ratu Suhita tidak lagi berbentuk persegi, tetapi berbentuk dasar lingkaran. Bentuk utamanya tetap mempertahankan bentuk sinar bersegi delapan, namun pada lingkaran pusat dikosongkan tanpa lagi ada figur Dewata Nawasangha. Gambaran Dewata Nawasangha justru dimunculkan padaa lingkaran luar setelah lingkaran bersegi delapan dengan pusat yang kosong. Arah kepala Dewata Nawasangha pun dibalik, jika masa Hayam Wuruk kepala dewa mengikuti pancaran sinar matahari yaitu keluar, namun era Dyah Suhita jutru mengarah ke dalam. Diantara figure Dewata Nawasangha pun mendapat tambahan delapan pancaran yang berada di sela-sela delapan pancaran utama. Yang diasosiasikan sebagai Lokapala atau dewa avatara dari Dewata Nawasangha.

Surya Majapahit yang ditemukan seringkali berada pada bagian atap candi di tengah-tengah tumpangsari candi. Hal tersebut masih dapat ditemukan pada candi angka tahun di kompleks percandian Panataran atau candi palah, serta pada candi Bangkal di Trowulan. Wujudnya adalah relief yang terbuat dari batu yang dipahat, sehingga warna yang dimunculkan adalah warna batu yang dibuat menjadi relief Surya 
Majapahit tersebut. Terkadang relief Surya Majapahit juga terpahat pada bagian badan candi, sebagaimana yang ditemukan pada candi Sawentar di Blitar.

\section{Kontras}

Dalam sebuah karya seni rupa dibutuhkan adanya kontras untuk memberikan efek keruangan dalam sebuah karya seni rupa. Kontras pada Surya Majapahit muncul dari hasil pahatan relief sehingga ada yang cekung dan timbul. Hasil dari pahatan tersebut memunculkan figur yang dapat diindera sehingga unsur-unsur seni rupa pada lambang Surya Majapahit terlihat jelas.

\section{Garis}

Garis dalam seni lukis mempunyai peran yang penting. Garis dapat merupakan batas suatu benda sekaligus juga memancarkan ekspresi dari pembuatnya. Dari sapuan sebuah garis dapat ditangkap kesan dari sebuah karya seni rupa. Dalam lambang Surya Majapahit garis tampak secara tegas sebagai outline yang membatasi antara objek sehingga antar figur dalam lambang tersebut mudah diidentifikasi perbedaannya. Garis dihasilkan dari pahatan yang timbul di relief lambang Surya Majapahit.

\section{Tekstur}

Pahatan yang dibuat pada lempengan batu candi tentulah memunculkan nilai raba dari suatu permukaan atau disebut tekstur. Tekstur yang muncul merupakan tekstur nyata, yaitu apa yang dilihat dan diraba memiliki nilai ungkap sama. Bentuk gambar yang muncul serta pori batu pada relief lambang Surya Majapahit akan dirasakan oleh indra peraba sesuai wujud yang ada

\section{Komposisi}

Komposisi relief lambang Surya Majapahit disusun dengan keseimbangan yang bersifat simetris untuk mencapai kesatuan bentuk. Komposisi yang proporsional dengan objek utama adalah pancaran sinar bersegi delapan nampak sangat presisi, seolah dibuat menggunakan teknik melalui perhitungan yang sangat matematis. Sehingga jarak antar pancaran, tinggi dan lebar figur dewa, wujud lingkaran terlihat sangat presisi. 


\section{Irama atau Ritme}

Lambang Surya Majapahit meskipun memiliki irama yang repetitif, namun tidak monoton. Ketidakmonotonan lambang Surya Majapahit dimunculkan dari bentuk-bentuk dewa yang berbeda-beda yang dapat dikenali dari senjata yang dibawa oleh masingmasing dewa.

\section{Centre of Interest atau Pusat Perhatian}

Pusat perhatian adalah aspek penting dalam karya seni rupa. Dengan adanya pusat perhatian dapat dilihat tema utama sebuah karya seni. Dalam lambang Surya Majapahit, pusat perhatian adalah pada pancaran sinar bersegi delapan. Keberadaan figur Dewata Nawasangha seolah lebih menjadi penerang atas makna yang terdapat pada pancaran sinar bersegi delapan tersebut.

Dari paparan struktur visual lambang Surya Majapahit selanjutnya memasuki tahap pelacakan pada gaya karya seni berdasarkan perbandingan dengan lambang dengan bentuk dasar matahari yang lain. Pemahaman mengenai gaya sebuah karya seni rupa merupakan syarat yang tidak bisa dihindari dalam mempelajari sejarah seni rupa. Gaya karya seni akan memperlihatkan kecenderungan-kecenderungan ekspresi visual yang bisa dikelompokkan atau diklasifikasikan untuk menentukan gaya berdasar waktu, wilayah, teknik, subject matter, dan lain sebagainya.

Dengan memperoleh pemahaman mengenai gaya karya seni akan membantu untuk membaca "hidden language" dari karya seni tersebut. Gaya karya seni sendiri dapat dideteksi melalui unsur-unsur seni rupa dan hubungan kualitatif antara elemenelemennya. Untuk memperoleh kepastian mengenai gaya karya seni, pada tahapan ini juga akan diperbandingkan dengan karya-karya lambang institusi lain yang menggunakan bentuk dasar matahari.

Perbandingan ini untuk melihat gaya dari lambang-lambang tersebut. Lambang Mangkunegaran, lambang organisasi Muhammadiyah dan turunanya, lambang Persis, lambang UIN, hingga lambang PAN dijadikan sebagai pembanding terhadap lambang Surya Majapahit. Karya seni ini mempunyai kemiripan tema dengan karya seni lambang Surya Majapahit, yaitu memiliki bentuk dasar Matahari yang dimunculkan sebagai bentuk utamanya dalam lambang. 

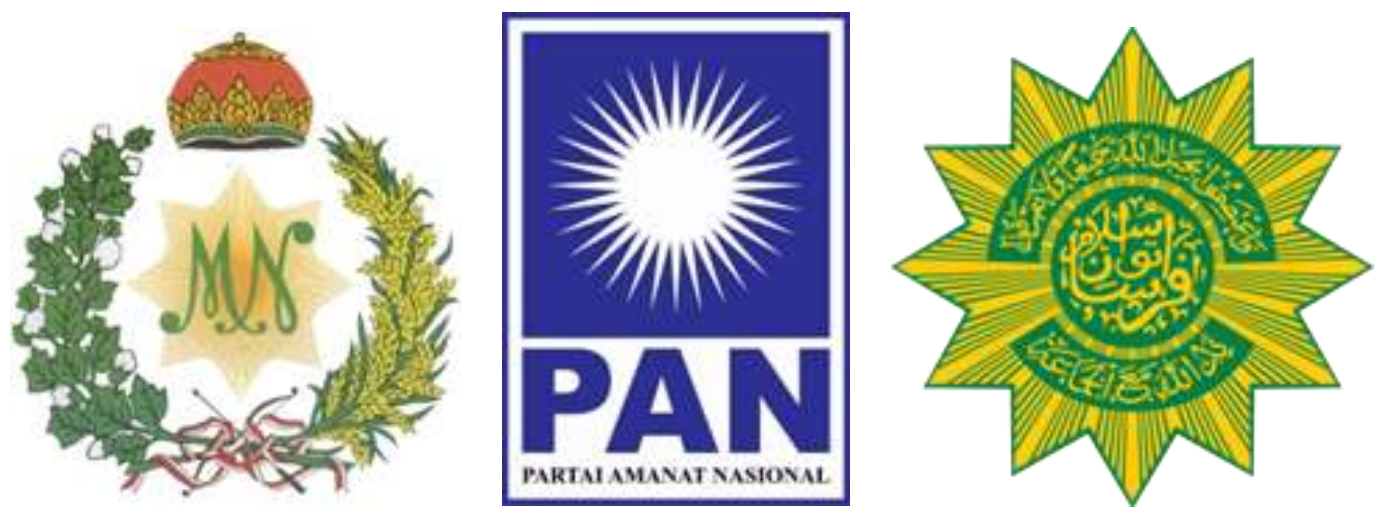

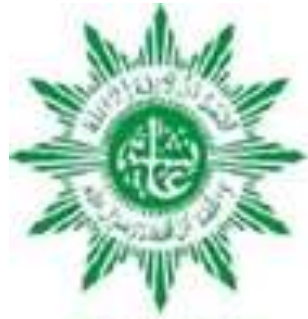

AISYIYAH

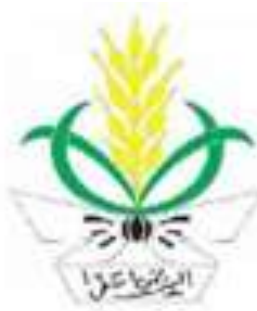

NASYIATUL AISYTYH

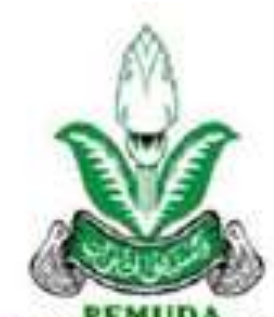

PEMUDA

MUHAMMADIYAH

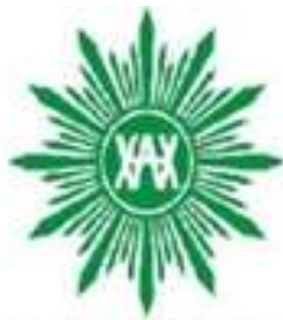

HIZBUL WATHAN

\section{WE ARE THE BIG FAMILY OF MUHAMMADIYAH}
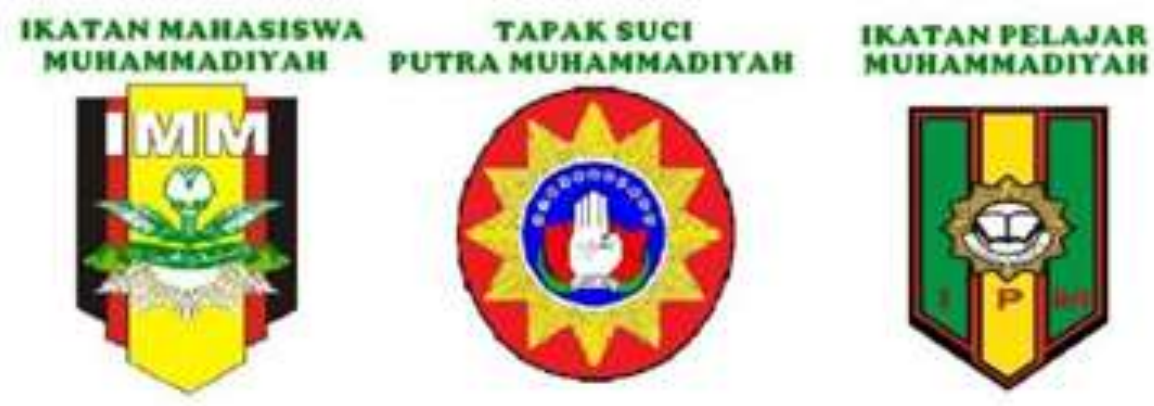

Gambar 02. Lambang Mangkunegaran, Partai Amanat Nasional dan PERSIS (Atas: dari kiri ke kanan). Bawah: Lambang PERSIS serta Lambang Muhammadiyaah dan anak organisasi Muhammadiyah

Kelima lambang tersebut yaitu Mangkunegaran, PAN, Persis, Muhammadiyah, serta IAIN/ UIN, merupakan sedikit dari lambang yang memiliki kesamaan dengan lambang Surya Majapahit. Karakter khasnya adalah pancaran sinar, baik tetap menggunakan segi delapan ataupun pengembangannya, namun tanpa melakukan perubahan yang signifikan karena bentuk dasar matahari masih dapat terlihat jelas. 

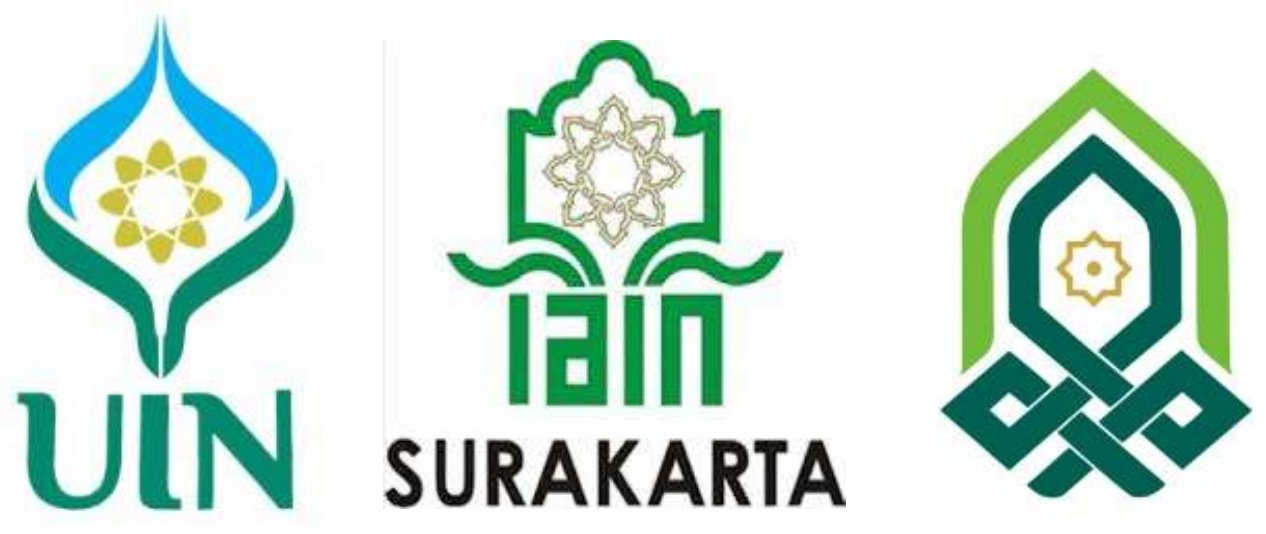

Gambar 3. Lambang Perguruan tinggi berdasar agama Islam yaitu UIN dan IAIN

Garis-garis dalam lambang-lambang tersebut bukanlah sebagai outline dari bentuk-bentuk yang ada dalam lambang tersebut. Garis dihadirkan lebih mengasosiasikan penggambaran pancaran yang mengarahkan pada penggambaran pancaran cahaya dalam konteks ini adalah pancaran matahari. Sehingga lambanglambang tersebut berasosiasi pada bentuk matahari yang di deformasi menjadi bentukbentuk baru sesuai dengan makna dari lambang yang dihadirkan.

Berdasarkan analisis formal di atas dan proses komparasi dengan beberapa lambang yang lain kemudian dikoreksi menggunakan teori mengenai gaya yang dikemukakan oleh Feldman maka gaya karya seni lambang instansi dengan bentuk dasar matahari bisa dikategorikan ke dalam gaya susunan formal (formal order), yaitu, merupakan karya seni yang diciptakan melalui aplikasi pola ukuran yang metodik untuk mencapai keseimbangan, stabilitas, dan keindahan. Selanjutnya Feldman juga menyatakan bahwa gaya juga bisa diklasifikasikan menurut tekniknya. Berdasarkan teknik yang digunakan gaya karya seluruh lambang instansi dengan bentuk dasar matahari tersebut dapat dikategorikan sebagai gaya simbolisme yang merupakan implementasi dari aliran simbolisme.

Suatu aliran seni rupa yang muncul pada akhir abad 19. Karya-karya aliran simbolisme mencoba membuat image visual yang mekspresikan ide. Cara menampilkan karya seninya untuk menyampaikan sesuatu yang simbolis dan lebih kepada spiritual reality (Adi Kusrianto dan Made Arini, 2011, hlm 122). Walaupun Surya Majapahit sudah 
muncul pada abad ke 15, namun pengklasifikasian gaya dimasukkan ke dalam aliran atau gaya simbolisme menurut ciri khas atau karakteristik gaya tersebut yang telah dikemukakan di atas.

\section{B. Tahap Kedua: Ikonografi}

Pada tahap kedua atau tahap ikonografi berupa identifikasi makna sekunder. Proses identifikasi bersumber dari pembacaan aspek-aspek tekstual karya seni dan melihat hubungannya dengan konteksnya untuk memperoleh pemahaman mengenai tema dan konsep karya tersebut. Sebagai prinsip korektif dibutuhkan pembandingan dengan sejarah tipe.

Tema diartikan sebagai suatu sumber penciptaan yang menarik minat seorang seniman dan menjadi atau dijadikan sebagai pengutamaan studi seninya. Pada akhirnya suatu tema menjadi konsepsi tentang apa saja dari seniman yang disampaikan atau diamanatkan melalui karya seninya (Agus Burhan, 2003). Konsep sendiri menurut Carrol (dalam Yulimarni, 2011) merupakan upaya filosofis untuk menggali pemikiran dan penciptaan yang mendasari terbentuknya suatu objek seni, dengan cara menguraikannya menjadi komponen-komponen terpisah dan setiap komponen ditetapkan sifat-sifatnya serta kegunaannya.

Tahap kedua ini akan dimulai dengan memahami aspek konteks lambang intansi dengan bentuk dasar matahari yang kemudian akan dianalisis tiap bagian dari karya seni tersebut yang mempunyai keterkaitan dengan tipe-tipe pada zaman tersebut. Pembacaan terhadap karya dengan menggunakan pendekatan ikonografi juga membutuhkan bukti-bukti literer karena di dalam pembuatannya juga melibatkan suatu studi panjang dan mendalam mengenai aspek sosial, budaya, politik,dan ekonomi.

Sebuah lambang khususnya kerajaan pastilah memiliki makna di balik wujudnya. Selain juga mampu menggambarkan ideologi kerajaan, tatanan yang digunakan dalam kerajaan, ataupun makna lain yang masih bersifat tacid. Terlebih ketika artifat tersebut telap dilestarikan tentulah memiliki ajaran yang mendalam bagi manusia Jawa. Ketertarikan manusia Jawa menggunakan lambang dalam wujud artifak merupakan salah satu petunjuk adanya perilaku simbolis yang tak dapat dipisahkan dari sistem budaya Jawa, oleh sebab itu terdapat istilah wong Jawa nggone semu. Dalam dunia orang Jawa, banyak hal yang tidak diejawentahkan secara tersurat, namun menggunakan bahasa-bahasa simbol yang tersirat tetapi memiliki makna yang dalam. $\mathrm{Hal}$ ini pun yang dimungkinkan dalam perwujudan surya Majapahit sebagai lambang kehidupan manusia Jawa yang tetap dilestarikan bahkan hingga kini. 
Lambang Surya Majapahit merupakan hasil perpaduan dua kepercayaan yaitu agama Hindu-Budha dan agama asli yang dijadikan sebagai lambang kerajaan Majapahit pada masanya. Terdapat unsur kepercayaan asli ditandai dengan adanya bentuk matahari dan banyaknya sudut sinar yang mengacu pada 8 arah mata angin. Sedangkan unsur agama Hindu, berkaitan dengan bentuk dewa-dewa yang berada di dalam matahari, dimana dewa-dewa tersebut merupakan dewa yang dikenal dalam agama Hindu yang dikenal dengan sebutan Dewata Nawasanga. Serta dewa Lokapala yang menjadi penjaga arah mata angin.

Dewata Nawasanga merupakan sembilan aspek Hyang Widhi (Esa dalam banyak) sebagai dewa Siwa, yang mengisi semua penjuru mata angin. Di timur dewa Iswara, Tenggara dewa Maheswara, Selatan dewa Brahma, Barat Daya dewa Rudra, Barat Dewa Mahadewa, Barat Laut Dewa Sangkara, Utara dewa Wisnu, dan Timur Laut dewa Sambhu (Kementrian Agama RI Ditjen Bimas Hindu (Parisada Hindu Dharma Indonesia). 2014, hlm. 47).

Aspek yang terkandung dalam lambang Surya Majaphit dengan bidang geometris bersegi delapan pun dilestarikan pula oleh penerus kerajaan Majapahit. Sebagai suatu bentuk legitimasi penerus kerajaan yang pernah jaya di Nusantara, serta pewaris asli tahta Majaphit, maka Mangkunegaran memunculkan lambang Surya pula dengan nama Surya Sumunar atau Surya Sumirat. Walaupun kerajaan ini lebih dipercaya sebagai kerajaan Islam, namun pandangan Hinduistik tidak dapat dilepaskan dari penggambaran lambang Mangkunegaran.

Karena pada awalnya, kebudayaan Jawa yang dihasilkan pada masa HinduBudha lebih bersifat terbuka, maka dalam perkembangan selanjutnya pun demikian. Demikian pula saat Islam berkembang pesat, manusia Jawa memahami bahwa semua agama baik dan benar, yang penting pengamalan setiap agama harus ditunjukkan bagi kepentingan dan kebesaran masyarakat. Sebagaimana diungkap dalam Wedatama bahwa Agama iku ageming aji, maka sangatlah wajar jika kebudayaan Jawa bersifat sinkretis (bersifat momot atau memuat). Sehingga meskipun Islam berkembang pula setelah Hindu-Budha, pengaruh Hindu-Budha serta kepercayaan purba yaitu animismedinamisme tentang kekuatan alam serba magis tetap akan dipertahankan bahkan berkembang (Simuh, 1999, hlm 117 dan 132).

Dari visualisasi lambang Majapahit inilah keraton Mangkunegaran yang apabila dilihat dari sisi sejarahnya, Mataram Islam masih memiliki hubungan dengan kerajaan 
Majapahit. Melestarikan tradisi budayanya dengan menampilkan gambar surya pada lambang keratonnya. Lambang Mangkunegaran yaitu Suryasumunar. Bentuk pancaran sinar matahari bersegi delapan tetap dipertahankan. Bahkan hingga ajaran yang terkandung di dalamnya pun masih mengacu pada ajaran hastabrata yang telah berkembang sejak zaman Hindu-Budha. Arti karta Surya Suminar sebagai lambang Mangkunegaran baru dimunculkan era Mangkunegara III. Surya berarti matahari, sedangkan Sunar artinya sinar, sirat atau cahaya. Suryasumunar atau Surya Sumirat berarti matahari bersinar.

Perkembangan era Islam pada lambang dengan bentuk dasar matahari dimunculkan pada dua organisasi Islam yang awalnya dianggap radikal, sebab berarah pada puritanisasi Islam dengan anti pada TBC (Takhayul, Bid'ah, Churofat). Sebuah gerakan yang mendobrak tatanan yang berkembang pada masa itu. Organisasi tersebut adalah Muhammadiyah yang didirikan oleh K.H. Ahmad Dahlan tahun 1912 di Yogyakarta, dan Persatuan Islam (Persis) oleh H. Zamzam pada 12 September 1920 di Bandung. Pada lambang ini semburat sinar tidak lagi berjumlah delapan namun berubah menjadi dua belas.

Aspek yang melatari kemunculan dua organisasi Islam awalnya sama, yaitu meluruskan agama Islam sesuai Al Qur'an dan Sunnah Nabi Muhammad SAW. Sehingga praktik-praktik yang tidak sesuai dengan tuntunan Islam harus ditinggalkan, karena bagi kedua organisasi ini, melakukan hal yang tidak dituntunkan Rasulullah adalah sia-sia, bahkan perbuatan bid'ah dapat membawa ummat pada kesesatan (Mark R. Woodward, 1999, hlm 326). Sehingga pancaran sinar matahari yang digunakan dalam lambang lebih mengacu pada pencerahan ajaran agama Islam, jika tidak ingin dikatakan sebagai pemurnian atau puritanisasi Islam.

Sedang lambang instansi dengan bentuk dasar matahari lain yaitu lambang UIN/IAIN serta PAN hampir memiliki kesamaan tema dengan lambang Muhammadiyah dan Persis. Karena lambang tersebut bukan lagi lambang yang jauh dari legitimasi kejayaan masa lampau, terlebih telah mengacu pada Islam modern, maka bentuk lambang pun lebih diasosiasikan kepada makna praktis.

Pada lambang IAIN/UIN lebih kepada pencerahan dalam bidang ilmu dan pengetahuan sehingga menggambarkan pacaran dari ilmu pengetahuan itu sendiri. Sedangkan bentuk matahari pada lambang PArtai Amanat Nasional (PAN), sangat terlihat jelas bahwa itu gambar matahari, tidak seperti yang lain yang lebih bersifat simbolis. Namun tidak berarti lambang PAN tanpa makna, kemunculan PAN sebagai parta progresif di era Reformasi pasca Orde Baru dengan tokohnya Amin Rais sebagai 
bapak Reformasi. Menjadikan PAN dianggap sebagai partai yang memberikan pencerahan bagi politik di Indonesia pada masa itu. Sehingga Mulai dari Lambang Muhamadiyah, Persis, IAIN/UIN, hingga PAN, lambang matahari lebih mengasosiasikan pada aspek tertentu, yaitu Islam, ilmu pengetahuan, dan aspek gerakan politik. Namun muaranya sama, yaitu memberikan pencerahan sesuai zamannya dan aspek yang melingkupinya. Sedangkan lambang Surya Majapahit dan lambang Mangkunegaran masih mengacu pada konsep ajaran dan falsafah Jawa, sekaligus sebuah legitimasi atas pendahulunya.

\section{Tahap Ketiga: Ikonologis}

Dalam tahap ini akan dilakukan pemaknaan terhadap lambang instansi dengan bentuk dasar matahari berdasarkan intuisi sintetik yang dipengaruhi oleh kondisi psikologi dan pandangan hidup dari penulis. Selain itu digunakan prinsip korektif berupa gejala-gejala kultural dan teori simbol dari Suzanne K. Langer.

Menurut Langer, simbol dibedakan menjadi dua jenis, yaitu: simbol seni dan simbol di dalam seni. Simbol seni disebut juga dengan bentuk ekspresi, sebagai ekspresi dari jalinan antara sensibilitas, emosi, perasaan, dan kognisi impersonal, yang merupakan ciri utama dari karya seni. Simbol seni dikatakan juga sebagai citra absolut (tidak terbatas), citra yang sebaliknya akan menjadi irasional karena secara harfiah tidak tergambarkan. Sementara yang dikatakan simbol di dalam seni adalah arti perlambangan yang dimuatkan pada karya tersebut atau sebuah metafora, sebuah citra dengan signifikansi harfiahnya yang jelas ataupun tersamar. Dengan demikian, menurut Langer, seni adalah sebuah simbol dan sekaligus juga bermuatan simbol (Suzzane K. Langer, 2006: 139-140).

Simbol pada lambang instansi dengan bentuk dasar matahari terbagi menjadi dua poros yaitu tradisi yang terpahami pada lambang Surya Majapahit dan lambang Mangkunegaran, serta modern yang lebih mengutamakan makna pragmatis yang mengarah pada makna praktis. Hal tersebut tergambarkan pada lambang Muhammadiyah, Persis, IAIN/UIN, serta PAN.

Makna pada Surya Majapahit dan Surya Sumirat yang menggambarkan Dewata Nawasangha menggambarkan suatu hubungan antara jagad gedhe (Astadikpalaka) serta jagad cilik (Pancamaya) yang tersimpan di dalam hati sanubari manusia yang merupakan pencerminan atau penggambaran dari ajaran Hastabrata. Ajaran tersebut 
merupakan simbolisasi laku manusia sebagai pemimpin, paling tidak menjadi pemimpin bagi dirinya sendiri agar mampu menjadi manusia utama. Ajaran Hastabrata yaitu delapan laku utama yang terdiri atas:

a. laku hambeging Kisma: seorang pemimpin yang selalu berbelas kasih dengan siapa saja. Kisma artinya tanah. Tanah tidak mempedulikan siapa yang menginjaknya, semua dikasihani. Tanah selalu memperlihatkan jasanya. Walaupun dicangkul, diinjak, dipupuk, dibajak tetapi malah memberi subur dan menumbuhkan tanaman. Filsafat tanah adalah air tuba dibalas air susu. Keburukan dibalas kebaikan dan keluhuran;

b. laku Hambeging Tirta: seorang pemimpin harus adil seperti air yang selalu rata permukaannya. Keadilan yang ditegakkan bisa memberi kecerahan ibarat air yang membersihkan kotoran. Air tidak pernah emban oyot emban cindhe 'pilih kasih';

c. laku Hambeging Dahana:seorang pemimpin harus tegas seperti api yang sedang membakar. Namun melalui pertimbangan berdasarkan akal sehat yang dapat dipertanggungjawabkan sehingga tidak membawa kerusakan di muka bumi;

d. laku Hambeging Samirana: seorang pemimpin harus berjiwa teliti di mana saja berada. Baik buruk rakyat harus diketahui oleh mata kepala sendiri, tanpa menggantungkan laporan dari bawahan saja. Bawahan cenderung selektif dalam memberi informasi untuk berusaha menyenangkan pimpinan;

e. laku Hambeging Samodra: seorang pemimpin harus mempunyai sifat pemaaf sebagaimana samudra raya yang siap menampung apa saja yang hanyut dari daratan. Jiwa samudra mencerminkan pendukung pluralisme dalam hidup bermasyarakat yang berkarakter majemuk;

f. laku Hambeging Surya:seorang pemimpin harus memberi inspirasi pada bawahannya ibarat matahari yang selalu menyinari bumi dan memberi energi pada setiap makhluk; laku Hambeging Candra:seorang pemimpin harus memberi penerangan yang menyejukkan seperti bulan bersinar terang benderang namun tidak panas, bahkan seperti terang bulan tampak indah sekali. Orang desa seringkali menyebutnya dengan istilah purnama sidi;

g. laku Hambeging Kartika: Maknanya seorang pemimpin harus tetap percaya diri meskipun dalam dirinya ada kekurangan. Ibarat bintang-bintang di angkasa, walaupun sangat kecil tapi dengan optimis memancarkan cahayanya, sebagai sumbangan buat kehidupan (Purwadi. 2007, hlm. 126-127). 
Demikian pula saat melihat kerlip bintang di angkasa, dapat menenangkan dan menentramkan hati dan perasaan. Demikianlah perilaku yang seharusnya menjadi watak bagi seorang pemimpin.

Pada Lambang Muhammadiyah, matahari merupakan titik pusat dalam tata surya dan merupakan sumber kekuatan semua makhluk hidup yang ada di bumi. Jika matahari menjadi kekuatan cikal bakal biologis, maka Muhammadiyah diharapkan dapat menjadi sumber kekuatan spiritual dengan nilai-nilai Islam yang berintikan dua kalimat syahadat. Dua belas pancaran sinar matahari sebagai tekad dan semangat Muhammadiyah dalam memperjuangkan Islam, semangat pantang menyerah seperti kaum Hawari (sahabat nabi Isa yang berjumlah 12). Warna Putih pada gambar matahari melambangkan kesucian dan keikhlasan. Warna dasar hijau melambangkan kedamaian dan dan kesejahteraan (http://www.muhammadiyah.or.id/id/content-53-det-cirikhas.html).

Makna lambang PERSIS hampir mirip dengan Muhammadiyah, bedanya pancaran sinar matahari berjumlah 12 mengacu pada tanggal berdirinya organisasi Persatuan Islam (Persis) (Ahmad Masur, 2012, hlm 15). Sedangkan makna simbol pada lambang UIN/IAIN lebih berasosiasi pada pencerahan dalam bidang ilmu pengetahuan Agama Islam sesuai kepanjangan dari IAIN dan UIN sebagai perguruan tinggi Islam di Indonesia. Sehingga dengan keilmuan dan pengetahuan mampu memberikan pencerahan dalam kehidupan di Dunia menuju ke akhirat. Sedangkan asosiasi PAN cenderung pada pencerahan di bidang politik yang pada eranya muncul sebagai pendobrak rezim yang berkuasa selama 32 tahun, sehingga jumlah pancaran 32 pada lambang PAN bermakna pencerahan dari belenggu rezim orde baru menuju tatanan baru yaitu reformasi.

Namun dari seluruh lambang institusi yang menggunakan bentuk dasar matahari, memiliki satu kesamaan. Masing-masing beranggapan sebagai pusat atau poros pada aspek sesuai konsep masing-masing. Lambang-lambang dengan bentuk dasar matahari sama-sama beranggapan sebagai merupakan poros kosmis, pusat, titik asal muasal, akar segala akar, sangkan paran, atau axis mundi. Dalam banyak segi, kosmologi agama Jawa yang tercermin dalam lambang dengan bentuk dasar matahari meluas, mengintegrasikan pengetahuan alam dan kepercayaan metafisika, sebagaimana tercermin dalam sistem pemerintahan, kepercayaan atau agama, 
kemasyarakatan, ilmu pengetahuan maupun politik masyarakat pendukung lambanglambang tersebut.

\section{SIMPULAN}

Kesimpulan melalui kajian ikonografi kita bisa memperoleh pemahaman terhadap artefak lambang instansi dengan bentuk dasar matahari baik pada aspek tekstual, kontekstual maupun pemaknaan yang lebih subtil. Selain itu juga memberikan pemahaman bahwa karya seni mampu mengungkapkan fakta-fakta sosial dan mental suatu zaman dengan menggunakan konstruksi pengetahuan yang saling berkait dan mendukung. Dalam artikel ini telah memperoleh ikatan dengan konteksnya melalui analisis pada gaya atau aliran maupun tema yang menggambarkan aspek kepercayaan, sosial, budaya, politik,dan ilmu pengetahuan yang berkelindan dengan karya seni lambang instansi dengan bentuk dasar matahari.

Dari analisis formal di atas juga diperoleh kesimpulan bahwa karya seni karya lambang instansi dengan bentuk dasar matahari, sinkretisme ajaran maupun muara konsep akan terus berkembang baik bentuk maupun polanya, namun hakikat maknanya tidak akan berubah. Bahwasanya lambang-lambang dengan bentuk dasar matahari sama-sama beranggapan sebagai merupakan poros kosmis, pusat, titik asal muasal, akar segala akar, sangkan paran, atau axis mundi. Sehingga beranggapan sebagai sumber pencerah sebagaimana matahari yang mampu menjadi problem solving bagi problematika yang dihadapi pendukung lambang tersebut di zamannya.

\section{DAFTAR PUSTAKA}

Adi Kusrianto dan Made Arini, History of Art, Jakarta: Penerbit PT Elex Media Komplitudo, 2011.

Ahmad Mansur, Sejarah Organisasi Persatuan Islam, Bandung: Tamadun Suryanegara, 2012.

Feldman, Edmund Burke, Art As Image And Idea, New Jersey: Prentice Hall, Inc. 1967.

Gustami, Butir-butir Mutiara Estetika Timur; Ide Dasar Penciptaan Seni Kriya Nusantara, Yogyakarta: Prasista, 2007 
Holt, Claire, Art In Indonesia: Continuities And Change, Ithaca-New York: Cornel University Press, 1967.

Kementrian Agama RI Ditjen Bimas Hindu (Parisada Hindu Dharma Indonesia). 2014. Swastikarana Pedoman Agama Hindu Dharma. Jakarta: PT Mabhakti

Langer, Suzzane K. , Problematika Seni, Terj: FX. Widaryanto, 2006.

M. Agus Burhan, "Seni Rupa Modern Indonesia: Tinjauan Sosiohistoris", dalam AspekAspek Seni Visual Indonesia: Politik Dan Gender, Yogyakarta: Yayasan Seni Cemeti, 2003.

Panofsky, Erwin, Meaning In The Visual Arts, Chicago: The University of Chicago Press, 1955.

, Sinn und Deutung in der bildenden Kunts, Koln: DuMont, 1975.

Purwadi. 2007. Wayang Purwa. Yogyakarta: Panji Pustaka.

Read, Herbert, The Meaning of Art, New York: Praeger Publishers, Inc., 1972.

Simuh, Sufisme Jawa; Transformasi Tasawuf Islam ke Mistik Jawa, Yogyakarta: Penerbit Bentang Budaya, 1999.

Slamet Muljana, Tafsir Sejarah Nagarakretagama, Yogyakarta: LKiS, 2006

Woodward, Mark R., Islam Jawa; Kesalehan Normatif Versus Kebatinan, Yogyakarta: Penerbit LKiS, 1999

Yulimarni, "Tabut Subarang Tahun 2010 dalam Tradisi Muharram Masyarakat Pariaman di Sumatera Barat", Tesis, Pengkajian Seni ISI Yogyakarta, 2011.

Zoetmulder, P.J. “The Wajang as A Philosopical Theme” BKI, 1971.

INTERNET

http://www.muhammadiyah.or.id/id/content-53-det-ciri-khas.html 